in Great Britain is not characterised by the unanimity of the previous report. While endorsing the general conclusions that the Dyestuffs (Import Regulation) Act is achieving its main objects, that the production of dyes during recent years has been satisfactory, especially taking into account the depressed state of some of the principal consuming industries, and the tribute paid to the extension of the range of products, the quality of the output and the standard of research maintained, as well as the technical and scientific progress, the users representatives dissent from the recommendation of the main Committee that the Act be continued on its present basis for a period of three years. On this point, however, independent representatives on the Committee, Profs. G. T. Morgan and Jocelyn Thorpe, make the reservation that the period of continuance should be five years. They base this reservation on the depend. ence of the industry upon a systematic application of research and the considerable interval of time which invariably occurs between discovery in the research laboratory of a promising dye and its commercial exploitation.

Tre difference of opinion between the users representatives and the majority of the Committee appears to turn on questions of price, the formation of an international agreement and the imposition of a ten per cent tariff. The majority report observes that the effect of the recent agreement between Imperial Chemical Industries Ltd. and the continental makers has yet to be seen, but that there is no reason to anticipate a restriction of the output and activities of the British company. They consider, moreover, that the British makers are still implementing the undertaking to supply at world prices during the continuance of the Act. While the users recommend that the Act should lapse on December 31, 1932, there is no recommendation regarding the tariff, and the recommendation that arrangements should be made for British makers to obtain their supplies of benzene, toluene and xylene at prices corresponding to those paid by their foreign competitors is signed by all members of the Committee.

\section{Land Drainage}

The paper on "Land Drainage in England and Wales", read by Capt. J. C. A. Roseveare, chief engineer of the Ministry of Agriculture and Fisheries, at the winter meeting of the Institution of Water Engineers on December 2, possesses a special interest at the present time by reason of the prominent place occupied by the subject of flood prevention in government and scientific circles, as well as among the general public dwelling in areas subject to inundations as disastrous as those which took place in the Midlands in the earlier part of the present year and in the area of the Don in 1931. The paper commenced with a concise résumé of the origins and constitution of land drainage authorities in Great Britain prior to the passing of the Land Drainage Act of 1930, and proceeded to detail the eircumstances attending the institution of the Ouse Drainage
Commission of 1925 and the Doncaster Commission of 1926, followed by the Royal Commission on Land Drainage in 1927, the recommendations of which formed the basis of the Land Drainage Act of 1930 . The principal feature of this Act was the constitution of a series of catchment boards for the administration of drainage areas comprised within watershed lines to be laid down by the Ordnance Survey Department. The Report of the Royal Commission contained a list of 100 suitable catchment areas, but the Act of 1930 scheduled only 47 for immediate creation. Boards for 46 of these areas, covering 67 per cent of the total area of England and Wales, were actually set. up before November 1931.

\section{Catchment Boards}

Catchment Boards may consist of any number of members not exceeding 31, one member being appointed by the Minister of Agriculture and not less than two-thirds of the remainder by county councils and county borough councils, the whole or part of whose areas lies within the catchment area. As regards the functions of these bodies, Capt. Roseveare went on to state that the special sub-Committee on River Gauging of the Advisory Committee on Water, of which he himself was a member, reported that catchment boards were the proper authorities to undertake the systematic gauging of the rivers of England and Wales, and it advocated these investigations as a necessary preliminary for determining the provision required both for the conservation of water and for the voiding of surplus water in wet periods. Reference was made, in this connexion, to the leading article in NATURE of July 2 and to the discussion on the subject at the York meeting of the British Association in September, which has led to the formation of a special Committee, now sitting, "to inquire into the position of inland water survey in the British Isles and the possible organisation and control of such a survey by central authority". The remainder of Capt. Roseveare's paper was devoted to tabular data and general information, of great value for reference purposes, concerning the various catchment areas and their 'main rivers', with some detailed account of the engineering works recently executed in the basin and estuary of the Ouse.

\section{Geography in Current Affairs}

At his inaugural lecture in the chair of geography at Oxford on November 15, Prof. K. Mason, after referring to the development of the School of Geography under his predecessors, spoke more particularly of the geography of current affairs (Oxford : Clarendon Press, 1s. 6d. net). The subject should entail the study of the earth as the home of man, and a framework of geographical knowledge is an indispensable background in the conduct of human affairs. Many of our present-day troubles he traced to a neglect of the teachings of geography. Much of the guidance that we have for the future comes from a study of the historical past, but to be of use for the future it must be set in the geographical present. The geography of the past,

No. 3293, Vol. 130] 